"Impact of diversification on systemic risk of conventional banks listed on the Indonesia Stock Exchange"

\begin{tabular}{|c|c|}
\hline AUTHORS & $\begin{array}{l}\text { Musa Fresno (D https://orcid.org/0000-0003-4323-0351 } \\
\text { Dewi Hanggraeni (D) https://orcid.org/0000-0001-9806-2055 }\end{array}$ \\
\hline ARTICLE INFO & $\begin{array}{l}\text { Musa Fresno and Dewi Hanggraeni (2020). Impact of diversification on systemic } \\
\text { risk of conventional banks listed on the Indonesia Stock Exchange. Banks and } \\
\text { Bank Systems, 15(4), 80-87. doi:10.21511/bbs.15(4).2020.07 }\end{array}$ \\
\hline DOI & http://dx.doi.org/10.21511/bbs.15(4).2020.07 \\
\hline RELEASED ON & Wednesday, 09 December 2020 \\
\hline RECEIVED ON & Tuesday, 03 November 2020 \\
\hline ACCEPTED ON & Friday, 27 November 2020 \\
\hline LICENSE & $\begin{array}{l}(c) \text { EY } \\
\text { This work is licensed under a Creative Commons Attribution } 4.0 \text { International } \\
\text { License }\end{array}$ \\
\hline JOURNAL & "Banks and Bank Systems" \\
\hline ISSN PRINT & $1816-7403$ \\
\hline ISSN ONLINE & $1991-7074$ \\
\hline PUBLISHER & LLC "Consulting Publishing Company "Business Perspectives" \\
\hline FOUNDER & LLC "Consulting Publishing Company "Business Perspectives" \\
\hline$\sigma^{0}$ & $\begin{array}{l}\text { 三ニ } \\
\text { 三E }\end{array}$ \\
\hline NUMBER OF REFERENCES & NUMBER OF FIGURES \\
\hline 31 & 3 \\
\hline
\end{tabular}

(C) The author(s) 2021. This publication is an open access article. 


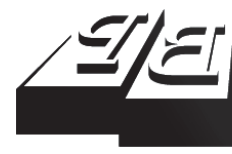

\section{BUSINESS PERSPECTIVES}

(2)

LLC "CPC "Business Perspectives"

Hryhorii Skovoroda lane, 10, Sumy, 40022, Ukraine

www.businessperspectives.org
Received on: $3^{\text {rd }}$ of November, 2020 Accepted on: 27th of November, 2020 Published on: $9^{\text {th }}$ of December, 2020

๑๐ Musa Fresno, Dewi Hanggraeni, 2020

Musa Fresno, Master of Management Program, School of Business and Economics, Prasetiya Mulya University, Indonesia.

Dewi Hanggraeni, Dr., Senior Lecturer, Faculty of Economics and Business, Department of Management, University of Indonesia, Indonesia. (Corresponding Author)

\title{
IMPACT OF DIVERSIFICATION ON SYSTEMIC RISK OF CONVENTIONAL BANKS LISTED ON THE INDONESIA STOCK EXCHANGE
}

\begin{abstract}
It is believed that bank diversification increases financial stability. However, several theories argue that diversification can trigger the spread of failure because of the increased interconnectivity between institutions. The aim of this study is to determine the impact of diversification on the systemic risk of banks. The sample of the study consists of 21 conventional banks listed on the Indonesia Stock Exchange from 2009 to 2018. The study uses firm-year fixed effect panel regression and an instrumental variable approach to examine how firm-specific variables determine the level of systemic risk. Diversification is measured by bank assets, funding, and revenue diversification. To measure the systemic risk, the Conditional Value-at-Risk $(\triangle \mathrm{CoVaR})$ methodology is applied. The results show that an increase in funding diversification leads to a decrease in $\triangle \mathrm{CoVaR}$, indicating that funding diversification exacerbates the level of systemic risk, whereas asset diversification and revenue diversification do not have significant effects on the level of systemic risk. The empirical findings suggest that the interconnectivity between banks should be reduced by limiting the diversification of funding in the banks to minimize their systemic risks.
\end{abstract}

Keywords

JEL Classification

\section{INTRODUCTION}

Banks play a major role in Indonesia, which has a bank-based financial system (Besar, 2012). Compared with other financial services, Indonesia's banking industry has the largest asset, with the proportion of bank assets in the total financial services sector continuing to grow since 2017 to reach 80.6 percent in 2019 (Financial Services Authority, 2020). The instability of one financial institution often spills over to other financial institutions, which can result in a severe shock to the economy (Zeb \& Rashid, 2019). The spread of such instability will increase systemic risk, which is the risk that the intermediation capacity of the entire financial system is impaired, and can result in reduced credit availability in the real economy (Adrian \& Brunnermeier, 2016). Moreover, financial crises incur substantial fiscal costs and output losses, averaging about 13.3 percent and 20 percent of GDP and can be as high as 55.1 percent and 98 percent of GDP, respectively (Valencia \& Laeven, 2008). In 2008, Bank Century (formerly known as Bank CIC) was declared as a failing bank by The Financial System Stability Committee (KSSK) and rescued by the Government of Indonesia with an IDR 6.7 trillion bailout to prevent a spillover (Manurung \& Moestafa, 2011). 
Financial regulators believe that diversification in banks can improve financial stability since it can minimize the likelihood of failure of an individual institution (Wagner, 2010), but the global financial crisis of 2007-2008 remained even though banks, especially large ones, had diversified their activities (Banwo et al., 2019). Banks begin to diversify their assets, funding, and revenue to face the increasing financial liberalization and innovation in the financial industry (Kim et al., 2020), without realizing that diversification can increase the spread of instability between institutions that will cause transmission of one institution's failure to other institutions, thereby increasing systemic risk and disrupting the stability of the financial system (Allen et al., 2012; Arinaminpathy et al., 2012; Banwo et al., 2019; De Jonghe, 2010; Kamani, 2019; Slijkerman et al., 2013; Wagner, 2010; Yang et al., 2019). Indonesia Banking Statistics shows that the ratio of revenue from nontraditional activities to interest revenue has increased from 35.1 percent in 2014 to 45 percent in 2019, indicating that banks rely more and more on nontraditional activities (Financial Services Authority, 2019).

Considering the movement towards nontraditional activities in Indonesia's banking industry and the potential negative impact of the movement on the financial system stability, this study explores the relationship between diversification and systemic risk. There are theories that provide similar arguments between diversification and systemic risk. However, empirical evidence of asset, funding, and revenue diversification as bank systemic risk factors, especially in developing countries, is still limited. Thus, this study fills in the gaps by providing empirical evidence on the systemic risk determinants of banks in Indonesia.

\section{LITERATURE REVIEW}

Systemic risk can be defined as the instability of a financial system caused by the transmission of its key market players to all other financial institutions (Zeb \& Rashid, 2019). Financial contagion comes through three channels such as common asset holdings, roll-over risk, and counterparty risk (Caccioli et al., 2014). The first line of literature argues that asset diversification increases systemic risk. Common asset holding drives the financial contagion when institutions fail and fire-sale their assets, which further decreases the price of the assets and causes the failure of other institutions with similar asset holding. Asset diversification leads to clustered asset structures, in which banks hold common asset portfolios (Allen et al., 2012). The commonality of asset holding caused by asset diversification increases systemic risk through the asset price contagion (Arinaminpathy et al., 2012). Loan portfolio risk of banks contributes to the increase in the systemic risk of a banking system (Bostandzic \& Weiß, 2018).

The second line of literature argues that funding diversification increases systemic risk. Roll-over risk occurs when creditors of a financial institution fail so that the financial institution that depends on the lending is no longer able to borrow and fails (Gai et al., 2011). Counterparty risk is the failure of an insti- tution caused by the inability of its borrowers to pay their debts (Staum, 2012). Roll-over risk and counterparty risk are driven by inter-institutional lending, which is a consequence of diversification (Caccioli et al., 2014). According to Ferrara et al. (2019), the inability of a bank to pay its interbank obligations will only cause the illiquidity of its creditors if the negative externality that arises from the inability to pay is adequately strong. Systemic risk is the aftermath of the interconnections among banks (Sato et al., 2019). Diversification of funding increases the non-core liabilities held by a bank, strengthens the interconnectivity between banks, and amplifies the effects of an aggregate shock (Barattieri et al., 2018). The amount of money market funding, which is a non-core funding, is positively related to the systemic risk of a bank (Moore \& Zhou, 2014). Banks with less diversified funding tend to have a higher deposit ratio and are less likely to be financed by securities issues, which implies that they are less connected to other financial institutions (Kleinow et al., 2017). Short-term wholesale funding, which is a non-core funding, is a key factor that triggers systemic risk events in a banking system (López-Espinosa et al., 2012).

The third line of literature argues that revenue diversification increases systemic risk. Banks increase diversification by moving into fee-based businesses, trading, and other activities to achieve economies of 
scale (Elsas et al., 2010). According to the too-complex-to-fail hypothesis, banks with diversified activities are more complex, therefore more difficult to manage and more opaque, hence more accustomed to riskier activities and increasing their systemic risk exposure (Kamani, 2019). Diversification of revenue in banks increases the risk of financial contagion (Yang et al., 2019). Banking systems that rely more on nontraditional activities, in which the non-interest income is relatively higher and the deposit to asset ratio is lower, tend to have lower systemic stability (Bostandzic \& Weiß, 2018). Non-interest income is positively correlated with a bank's interconnectedness risk and tail risk (Brunnermeier et al., 2019). Systemic risk of a bank is determined by its engagement with nontraditional activities, especially the amount of non-interest income from the fees and commissions (Moore \& Zhou, 2014).

\section{AIMS AND HYPOTHESES}

The purpose of this study is to determine the impact of asset, funding, and revenue diversification on the systemic risk of banks in Indonesia for the period 2009 to 2018 using Conditional Value-atRisk $(\triangle \mathrm{CoVaR})$ to measure the systemic risk and firm-year fixed effect panel regression with instrumental variables to examine the relationships. Based on the literatures, this study argues that bank diversification causes interconnectivity between banks and further leads to risk contagion among banks. The study hypothesizes that bank diversification increases systemic risk:

\section{$H_{1}: \quad$ Asset diversification increases systemic risk.}

$\mathrm{H}_{2}: \quad$ Funding diversification increases systemic risk.

$\mathrm{H}_{3}: \quad$ Revenue diversification increases systemic risk.

\section{METHODS}

\subsection{Model specification}

This study follows Yang et al. (2019) to examine if bank diversification affects systemic risk. Diversification of banks can trigger instability con- tagion between institutions, thereby increasing systemic risk and disrupting the stability of the financial system (Allen et al., 2012; Arinaminpathy et al., 2012; Banwo et al., 2019; De Jonghe, 2010; Kamani, 2019; Slijkerman et al., 2013; Wagner, 2010; Yang et al., 2019).

Panel data for the period 2007-2018 were collected from 21 publicly traded banks in Indonesia, resulting in 210 firm-year observations. Data used in this study were obtained from Thomson Reuters, Yahoo Finance, Indonesia Bond Pricing Agency, BankFocus, and bank annual reports. Hausman tests were conducted to determine if a fixed effect model is suitable. To examine the determinants of systemic risk, two-stage least squares (2SLS) panel regression with firm-year fixed effect was used to address the endogeneity of diversification variables are affected by EBT to sales and bank size. Banks with low profitability tend to diversify to increase their profits, while banks with larger total assets tend to have more diversified activities (Campa \& Kedia, 2001; Carey \& Stulz, 2013; Demsetz \& Strahan, 1997). Consequently, size (log total assets) and EBT to sales were used as instrument variables. The first stage regression is as follows:

$$
\begin{aligned}
& \text { Diversification }_{i, t}= \\
& =\alpha+\gamma_{1} \text { Diversification }_{i, t-1}+\gamma_{2} \text { EBTS }_{i, t}+ \\
& +\gamma_{3} \text { EBTS }_{i, t-1}+\gamma_{4} \text { EBTS }_{i, t-2}+\gamma_{5} \text { SIZE }_{i, t}+ \\
& +\gamma_{6} \text { SIZE }_{i, t-1}+\gamma_{7} \text { SIZE }_{i, t-2}+\beta_{1} L_{L P R_{i, t}}+ \\
& +\beta_{2} L R_{i, t}+\beta_{3} \text { EAR }_{i, t}+\beta_{4} C I R_{i, t}+ \\
& +\beta_{5} L_{i, t}+\beta_{6} \text { SDR }_{i, t}+\beta_{7} \text { EM }_{i, t}+e_{i, t}
\end{aligned}
$$

where $i=$ bank, EBTS $=$ debt to sales, SIZE $=\log$ total assets, $L L P R=$ loan loss provision to loans, $L A R=$ loans to assets, $E A R=$ equity to assets, $C I R$ = operating cost to operating income, $L I Q=$ liquidity, $S D R=$ short-term borrowings to assets, and $E M=$ earnings management.

The second stage of two-stage least squares regression is as follows:

$$
\begin{aligned}
& \Delta \text { CoVaR }_{i, t}=\alpha+\gamma_{1} \overline{\text { Diversification }}_{i, t}+ \\
& +\beta_{1} \operatorname{LLPR}_{i, t}+\beta_{2} \operatorname{LAR}_{i, t}+\beta_{3} \text { EAR }_{i, t}+{ }_{4} C_{1, t}+ \\
& +\beta_{5} L I Q_{i, t}+\beta_{6} \operatorname{SDR}_{i, t}+\beta_{7} \text { EM }_{i, t}+e_{i, t}
\end{aligned}
$$


where $\Delta \mathrm{CoVaR}=$ Delta Conditional Value at Risk (systemic risk).

\subsection{Systemic risk measurement}

The measurement of the systemic risk follows Yang et al. (2019) and Adrian and Brunnermeier (2016). Quantile regressions for the 5\% and 50\% quantiles are conducted using stock market index (LQ45 Index) and financial system index (IDX Finance Index) weekly log returns as the dependent variables and macroeconomic data as the independent variables. The macroeconomic variables are liquidity spread (the spread between BI 7-day Repo Rate and Indonesia 0.1Y Government Bond), credit spread (the spread between Indonesia 10Y Corporate Bond yield and Indonesia 10Y Government Bond yield), and equity volatility (standard deviation of IDX Finance Index return). The estimates are then used to predict the value of market-level Value at Risk (VaR) of the LQ45 Index $\left(\mathrm{VaR}^{\mathrm{LQ} 45}\right)$ and the IDX Finance Index $\left(\mathrm{VaR}^{\mathrm{FIN}}\right)$.

Next, quantile regressions for the 5\% and 50\% quantiles are conducted using bank stock weekly $\log$ returns as the dependent variable, while market-level VaR and macroeconomic variables are used as independent variables. The estimates are then used to predict the Conditional Value at Risk (CoVaR), which indicates the expected maximum loss of an individual bank conditional upon the financial system (LQ45 and FIN) under distress (5\% quantile) and normal condition (50\% quantile). The additional risk that the financial system exposes to a certain bank when other banks are in a distressed condition, which is taken as the systemic risk, is calculated by taking the difference between CoVaR under distress and CoVaR under normal conditions. The results are then averaged yearly to be used as the dependent variable of the main regression.

\subsection{Diversification and control variables}

This study follows Yang et al. (2019) to measure diversification from three aspects such as asset diversification, funding diversification, and revenue diversification. The asset diversification (ADIV) is calculated as follows:

$$
\begin{aligned}
& A D I V=1-\left[\left(\frac{B L O A N}{E A}\right)^{2}+\left(\frac{C L O A N}{E A}\right)^{2}+\right. \\
& \left.+\left(\frac{G O V B}{E A}\right)^{2}+\left(\frac{C O R P B}{E A}\right)^{2}+\left(\frac{O S E C}{E A}\right)^{2}\right]
\end{aligned}
$$

where $B L O A N=$ bank loans, $C L O A N=$ customer loans, $G O V B=$ government bonds, $C O R P B=$ corporate bonds, $S E C=$ other securities, and $E A=$ total earning assets (sum of BLOAN, CLOAN, GOVB, $C O R P B$, and OSEC).

The funding diversification (FDIV) is calculated as follows:

$$
\begin{aligned}
& F D I V=1-\left[\left(\frac{E Q U I T Y}{F U N D}\right)^{2}+\left(\frac{I B D E P}{F U N D}\right)^{2}+\right. \\
& \left.+\left(\frac{C D E P}{F U N D}\right)^{2}+\left(\frac{S B O R}{F U N D}\right)^{2}+\left(\frac{S U B}{F U N D}\right)^{2}\right]
\end{aligned}
$$

where $E Q U I T Y=$ total equity, $I B D E P=$ interbank deposits, $C D E P=$ customer deposits, $S B O R=$ short-term borrowings, $S U B=$ subordinated debts, and $F U N D=$ total funding (sum of EQUITY, IBDEP, CDEP, SBOR, and SUB)

Revenue diversification is measured using two variables, namely revenue diversification (RDIV) and Adjusted Herfindahl-Hirschman Index (DHHI), and calculated as follows:

$$
\begin{aligned}
& R D I V=1-\left[\left(\frac{I N T}{T O R}\right)^{2}+\left(\frac{F E E}{T O R}\right)^{2}+\right. \\
& \left.+\left(\frac{T R A D}{T O R}\right)^{2}+\left(\frac{\text { OTREV }}{T O R}\right)^{2}\right]
\end{aligned}
$$

$D H H I=1-\left[\left(\frac{I N T}{T O R}\right)^{2}+\left(\frac{N O N I N T}{T O R}\right)^{2}\right]$,

where $I N T=$ interest revenue, $F E E=$ fees and commissions, TRAD = gains on trading, OTREV = other non-interest revenue, NONINT $=$ non-interest revenue, and $T O R=$ total revenue (sum of INT, FEE, TRAD, and OTREV). 
The earnings management measures the level of realized securities gains or losses (RSGL) and underreporting of loan loss provision (LLP) as part of the effort to smoothen incomes. The discretionary realized securities gains or losses (DRSGL) is the error term from a model in which RSGL is regressed using year fixed-effect panel regression with log total assets and unrealized security gains to total assets as the independent variables. The discretionary loan loss provision (DLLP) is the error term from a model in which LLP is regressed using year fixed-effect panel regression with log total assets, gross non-performing loan to total loans, loan loss allowance to total loans, commercial loan to total loans, interbank loan to total loans, and agriculture loan to total loans as the independent variables, transformed with the loans to assets ratio. To calculate earnings management (EM), DLLP is subtracted from DRSGL.

\section{RESULTS}

The Hausman tests were conducted to determine if fixed effect model best fits the regression. If the null hypothesis is rejected, the efficient and consistent model is the fixed effect. Table 1 shows that the null hypothesis of the Hausman test is rejected, therefore the fixed effect model is best suited for the regression.

Table 1. Hausman test

\begin{tabular}{c:c:c:c:c}
\hline $\begin{array}{c}\text { Hausman } \\
\text { test }\end{array}$ & (1) & (2) & (3) & (4) \\
\hline Prob. > Chi ${ }^{2}$ & 0.0000 & 0.0031 & 0.0011 & 0.0001 \\
\hline
\end{tabular}

Table 2 provides the estimates of the first stage regression. The proxies of diversification used in Models 1 and 2 are asset diversification and funding diversification, respectively. Models 3 and 4 use revenue diversification as a proxy of diversification. Revenue diversification in Model 3 divides revenues into interest revenue, fees and commissions, gains on trading, and other non-interest revenue, while revenue diversification in Model 4 divides revenue into interest revenue and non-interest revenue. The loans to assets (LAR) variable in Model 1 is omitted to address the correlation between the variable and asset diversification.
Table 2. First stage regression results

\begin{tabular}{|c|c|c|c|c|}
\hline \multirow{2}{*}{$\begin{array}{l}\text { Independent } \\
\text { variables }\end{array}$} & \multicolumn{4}{|c|}{ Dependent variable: diversification } \\
\hline & (1) & (2) & (3) & (4) \\
\hline Diversification $_{t-1}$ & $\begin{array}{c}0.4364^{* * *} \\
(0.058)\end{array}$ & $\begin{array}{c}0.1394^{* * *} \\
(0.051)\end{array}$ & $\begin{array}{c}0.247^{* * *} \\
(0.059)\end{array}$ & $\begin{array}{l}0.3021^{* * *} \\
(0.059)\end{array}$ \\
\hline EBTS & $\begin{array}{r}-0.1629 \\
(0.194)\end{array}$ & $\begin{array}{r}-0.0771 \\
(0.092)\end{array}$ & $\begin{array}{c}-0.2695^{*} \\
(0.154)\end{array}$ & $\begin{array}{r}-0.0609 \\
(0.135)\end{array}$ \\
\hline EBTS $_{t-1}$ & $\begin{array}{c}0.1319 * * * \\
(0.046)\end{array}$ & $\begin{array}{r}-0.0041 \\
(0.021)\end{array}$ & $\begin{array}{c}-0.0806^{* *} \\
(0.035)\end{array}$ & $\begin{array}{c}-0.086^{* * *} \\
(0.031)\end{array}$ \\
\hline EBTS $_{t-2}$ & $\begin{array}{c}-0.125^{* * *} \\
(0.047)\end{array}$ & $\begin{array}{r}-0.0139 \\
(0.023)\end{array}$ & $\begin{array}{r}-0.0006 \\
(0.038)\end{array}$ & $\begin{array}{l}0.0244 \\
(0.033)\end{array}$ \\
\hline SIZE & $\begin{array}{c}-0.0103 \\
(0.042)\end{array}$ & $\begin{array}{c}-0.0112 \\
(0.02)\end{array}$ & $\begin{array}{c}0.0756^{* *} \\
(0.033)\end{array}$ & $\begin{array}{l}0.0527^{*} \\
(0.029)\end{array}$ \\
\hline$S I Z E_{t-1}$ & $\begin{array}{c}-0.1255^{* *} \\
(0.056)\end{array}$ & $\begin{array}{r}-0.0217 \\
(0.027)\end{array}$ & $\begin{array}{c}-0.192^{* * *} \\
(0.045)\end{array}$ & $\begin{array}{c}0.1193^{* * *} \\
(0.04)\end{array}$ \\
\hline$S I Z E_{t-2}$ & $\begin{array}{c}0.1054^{* * *} \\
(0.039)\end{array}$ & $\begin{array}{c}0.0447^{* *} \\
(0.019)\end{array}$ & $\begin{array}{c}0.1348^{* * *} \\
(0.032)\end{array}$ & $\begin{array}{l}0.1021^{* * *} \\
(0.028)\end{array}$ \\
\hline$\angle L P R$ & $\begin{array}{c}0.9503^{* *} \\
(0.436)\end{array}$ & $\begin{array}{c}-0.8027 * * * \\
(0.213)\end{array}$ & $\begin{array}{c}2.3577^{* * *} \\
(0.351)\end{array}$ & $\begin{array}{c}2.2376 * * * \\
(0.306)\end{array}$ \\
\hline$L A R$ & (Omitted) & $\begin{array}{l}0.0058 \\
(0.05)\end{array}$ & $\begin{array}{c}-0.1642 * * \\
(0.082)\end{array}$ & $\begin{array}{l}-0.1647^{* *} \\
(0.072)\end{array}$ \\
\hline EAR & $\begin{array}{r}-0.1362 \\
(0.198)\end{array}$ & $\begin{array}{c}1.0428^{* * *} \\
(0.096)\end{array}$ & $\begin{array}{c}0.5178^{* * *} \\
(0.166)\end{array}$ & $\begin{array}{c}0.3666^{* *} \\
(0.142)\end{array}$ \\
\hline$C I R$ & $\begin{array}{r}-0.0754 \\
(0.213)\end{array}$ & $\begin{array}{c}-0.0292 \\
(0.101)\end{array}$ & $\begin{array}{c}-0.5394^{* * *} \\
(0.169)\end{array}$ & $\begin{array}{l}-0.2884^{*} \\
(0.148)\end{array}$ \\
\hline$L I Q$ & $\begin{array}{l}0.0543 \\
(0.091)\end{array}$ & $\begin{array}{l}0.0786 \\
(0.048)\end{array}$ & $\begin{array}{c}-0.1348^{*} \\
(0.079)\end{array}$ & $\begin{array}{l}-0.1252^{*} \\
(0.071)\end{array}$ \\
\hline$S D R$ & $\begin{array}{l}0.1684 \\
(0.317)\end{array}$ & $\begin{array}{c}1.3008^{* * *} \\
(0.16)\end{array}$ & $\begin{array}{l}0.0248 \\
(0.256)\end{array}$ & $\begin{array}{l}-0.1152 \\
(0.223)\end{array}$ \\
\hline$E M$ & $\begin{array}{c}1.6112^{* *} \\
(0.765)\end{array}$ & $\begin{array}{c}-0.705^{*} \\
(0.369)\end{array}$ & $\begin{array}{l}0.1257 \\
(0.608)\end{array}$ & $\begin{array}{l}0.8539 \\
(0.535)\end{array}$ \\
\hline Constant & $\begin{array}{l}1.2853 \\
(0.776)\end{array}$ & $\begin{array}{c}-0.2035 \\
(0.57)\end{array}$ & $\begin{array}{l}0.1407 \\
(0.99)\end{array}$ & $\begin{array}{l}-0.64 \\
(0.802)\end{array}$ \\
\hline N & 210 & 210 & 210 & 210 \\
\hline$R$-squared & 0.5296 & 0.8129 & 0.5083 & 0.5270 \\
\hline
\end{tabular}

Note: $* * *, * *$, and $*$ indicate variable significance at the 0.01 0.05 , and 0.1 significance levels, respectively. Standard errors in parentheses.

Table 3 provides the estimates of the second stage regression. Lower value of $\Delta \mathrm{CoVaR}$ indicates higher level of systemic risk. The estimates of Model 1 show a positive impact of asset diversification on $\triangle \mathrm{CoVaR}(0.0084)$, suggesting that asset diversification lowers systemic risk, while the estimates of Models 2-4 show a negative impact of funding and revenue diversification on $\triangle \mathrm{CoVaR}$ (FDIV -0.0798 , RDIV -0.0012 , and DHHI -0.0013), suggesting that funding and revenue diversification exacerbates systemic risk. However, asset and revenue diversification does not significantly affect systemic risk. Funding diversification significantly affects systemic risk under the 95 percent confidence level. 
Table 3. Diversification and systemic risk

\begin{tabular}{|c|c|c|c|c|}
\hline \multirow{2}{*}{$\begin{array}{l}\text { Independent } \\
\text { variables }\end{array}$} & \multicolumn{4}{|c|}{ Dependent variable: $\Delta$ CoVaR } \\
\hline & (1) & (2) & (3) & (4) \\
\hline$\widehat{\text { Diversification }}$ & $\begin{array}{l}0.0084 \\
(0.006)\end{array}$ & $\begin{array}{c}-0.0798^{* *} \\
(0.03)\end{array}$ & $\begin{array}{r}-0.0012 \\
(0.007)\end{array}$ & $\begin{array}{r}-0.0013 \\
(0.007)\end{array}$ \\
\hline$L L P R$ & $\begin{array}{l}0.0065 \\
(0.019)\end{array}$ & $\begin{array}{c}-0.07 * * \\
(0.031)\end{array}$ & $\begin{array}{l}0.0112 \\
(0.018)\end{array}$ & $\begin{array}{l}0.0114 \\
(0.017)\end{array}$ \\
\hline$L A R$ & (Omitted) & $\begin{array}{c}-0.0098^{*} \\
(0.005)\end{array}$ & $\begin{array}{r}-0.0078 \\
(0.006)\end{array}$ & $\begin{array}{r}-0.0078 \\
(0.006)\end{array}$ \\
\hline EAR & $\begin{array}{r}-0.0099 \\
(0.012)\end{array}$ & $\begin{array}{l}0.0737 * * \\
(0.033)\end{array}$ & $\begin{array}{r}-0.0121 \\
(0.014)\end{array}$ & $\begin{array}{r}-0.0125 \\
(0.014)\end{array}$ \\
\hline$C I R$ & $\begin{array}{c}-0.0036^{*} \\
(0.002)\end{array}$ & $\begin{array}{l}0.0026 \\
(0.003)\end{array}$ & $\begin{array}{r}-0.0029 \\
(0.002)\end{array}$ & $\begin{array}{r}-0.0029 \\
(0.002)\end{array}$ \\
\hline LIQ & $\begin{array}{r}-0.0001 \\
(0.005)\end{array}$ & $\begin{array}{l}0.0041 \\
(0.006)\end{array}$ & $\begin{array}{r}-0.0029 \\
(0.005)\end{array}$ & $\begin{array}{r}-0.0029 \\
(0.005)\end{array}$ \\
\hline$S D R$ & $\begin{array}{r}-0.0185 \\
(0.012)\end{array}$ & $\begin{array}{l}0.1013^{* *} \\
(0.039)\end{array}$ & $\begin{array}{r}-0.0163 \\
(0.011)\end{array}$ & $\begin{array}{r}-0.0164 \\
(0.012)\end{array}$ \\
\hline$E M$ & $\begin{array}{r}-0.0267 \\
(0.044)\end{array}$ & $\begin{array}{l}-0.0716 \\
(0.044)\end{array}$ & $\begin{array}{r}-0.0154 \\
(0.044)\end{array}$ & $\begin{array}{r}-0.0149 \\
(0.045)\end{array}$ \\
\hline Constant & $\begin{array}{c}-0.0235^{* * *} \\
(0.003)\end{array}$ & $\begin{array}{l}-0.0064 \\
(0.007)\end{array}$ & $\begin{array}{c}-0.0149 * * \\
(0.007)\end{array}$ & $\begin{array}{c}-0.0149^{* *} \\
(0.006)\end{array}$ \\
\hline N & 210 & 210 & 210 & 210 \\
\hline$R$-squared & 0.3711 & 0.4118 & 0.3711 & 0.3711 \\
\hline
\end{tabular}

Note: $* * *, * *$, and $*$ indicate variable significance at the $0.01,0.05$, and 0.1 significance levels, respectively. Standard errors in parentheses.

\section{DISCUSSION}

The results show that funding diversification significantly contributes to more severe systemic risk, providing strong evidence on hypothesis 2 . The finding provides empirical evidence that supports the roll-over risk theory explaining that the failure of a financial institution will spread out to another financial institution that depends on the lending of the failed institution (Gai et al., 2011), and the counterparty risk theory explaining that the failure of a borrower will affect the stability of its lenders (Staum, 2012), both of which are the aftermath of funding diversification (Caccioli et al., 2014).

Both asset and revenue diversifications measure the diversification of activities between traditional activities (loans and deposit) and nontraditional activities (trading, fee-and-commission based activities, and other non-interest income activities). The study finds that the relationship between diversification (asset and revenue) and systemic risk is statistically insignificant, suggesting that the movement towards nontraditional activities does not affect systemic risk. The evidence is based on normal conditions, as opposed to extreme events in which banks conduct fire-sale. Common asset holding theory explains that asset diversification exacerbates systemic risk through fire-sale spillovers (Caccioli et al., 2014). Perhaps, the absence of fire-sale spillovers in the Indonesian banking industry during the period 2009-2018 is the root of this finding. Moreover, banks in the sample have revenue diversification values of 0.22 and 0.20 (RDIV and DHHI, respectively), which are considerably lower compared to banks in the United States that have the average RDIV and DHHI value of 0.38 and 0.34 , respectively (Yang et al., 2019). Presumably, the degree of revenue diversification of banks in Indonesia is still too low to trigger the financial contagion.

\section{CONCLUSION}

Diversification is generally believed to reduce the risk of instability and systemic failure in the banking industry. However, recent theories and studies prove otherwise. This study contributes empirically to the area of research by exploring the empirical significance of the theory in a developing country with a relatively low bank activities diversification level, as the relationship between diversification and systemic risk varies among countries with different degrees of diversification. Using the sample of publicly traded banks in Indonesia and the two-stage least squares (2SLS) panel regression with firm-year fixed effect, this study estimates the relationship between diversification (asset, funding, and revenue) and systemic risk. The results provide significant evidence that funding diversification leads to higher systemic risk, supporting the rollover and counterparty risk theory, and indicating that the interconnectivity between banks that arises from funding diversification will trigger financial contagion. In the contrary, asset and revenue diversifications, both of which measure the diversification between traditional and nontraditional activities, do not have a significant impact on systemic risk. 
The study recommends that The Financial System Stability Committee (KSSK) should reduce the interconnectivity between banks by regulating diversification of funding in banks to reduce the likelihood of systemic failure and monitor banks with a high degree of funding diversification to predict which banks have a higher level of systemic risk. Banks are also recommended to benefit from asset and revenue diversification by diversifying into nontraditional activities as an effort to minimize idiosyncratic risk, since the findings suggest that systemic risk is not affected by the movement towards nontraditional activities.

\section{AUTHOR CONTRIBUTIONS}

Conceptualization: Musa Fresno, Dewi Hanggraeni.

Data curation: Musa Fresno, Dewi Hanggraeni.

Formal Analysis: Musa Fresno, Dewi Hanggraeni.

Funding acquisition: Musa Fresno, Dewi Hanggraeni.

Investigation: Musa Fresno, Dewi Hanggraeni.

Methodology: Musa Fresno, Dewi Hanggraeni.

Project administration: Musa Fresno, Dewi Hanggraeni.

Resources: Musa Fresno, Dewi Hanggraeni.

Supervision: Dewi Hanggraeni.

Visualization: Musa Fresno, Dewi Hanggraeni.

Writing - original draft: Musa Fresno, Dewi Hanggraeni.

Writing - review \& editing: Musa Fresno, Dewi Hanggraeni.

\section{REFERENCES}

1. Adrian, T., \& Brunnermeier, M. K. (2016). CoVaR. American Economic Review, 106(7), 17051741. https://doi.org/10.1257/ aer.20120555

2. Allen, F., Babus, A., \& Carletti, E. (2012). Asset commonality, debt maturity and systemic risk. Journal of Financial Economics, 104(3), 519-534. https://doi.org/10.1016/j. jfineco.2011.07.003

3. Arinaminpathy, N., Kapadia, S., \& May, R. M. (2012). Size and complexity in model financial systems. Proceedings of the National Academy of Sciences of the United States of America, 109(45), 1833818343. https://doi.org/10.1073/ pnas. 1213767109

4. Banwo, O., Harrald, P., \& Medda, F. (2019). Understanding the consequences of diversification on financial stability. Journal of Economic Interaction and Coordination, 14, 273-292. https://doi. org/10.1007/s11403-018-0216-9

5. Barattieri, A., Moretti, L., \& Quadrini, V. (2018). Banks Interconnectivity and Leverage
(Working Paper No. 2018-05). Retrieved from https://economie. esg.uqam.ca/wp-content/uploads/ sites/54/2018/01/2018_05_docdt_ eco.compressed.pdf

6. Besar, D. S. (2012). Indonesian Banking Development: Financial services liberalization, the regulatory framework, and financial stability. Proceedings from Workshop on Trade in Financial Services and Development. Geneva. Retrieved from https://www.wto. org/english/tratop_e/serv_e/wkshop_june12_e/besar_e.pdf

7. Bostandzic, D., \& Weiß, G. N. F. (2018). Why do some banks contribute more to global systemic risk? Journal of Financial Intermediation, 35(A), 17-40. https://doi. org/10.1016/j.jfi.2018.03.003

8. Brunnermeier, M. K., Dong, G. N., \& Palia, D. (2019). Banks' NonInterest Income and Systemic Risk. Review of Corporate Finance Studies, 9(2), 229-255. https://doi. org/10.2139/ssrn.3328890

9. Caccioli, F., Shrestha, M., Moore, C., \& Farmer, J. D. (2014). Stability analysis of financial contagion due to overlapping portfolios. Journal of Banking and Finance, 46, 233-245. https://doi.org/10.1016/j. jbankfin.2014.05.021

10. Campa, J. M., \& Kedia, S. (2001). Explaining the Diversification Discount. SSRN Electronic Journal. https://doi.org/10.2139/ ssrn.264763

11. Carey, M., \& Stulz, R. M. (Eds.) (2013). The Risks of Financial Institutions. University of Chicago Press. https://doi.org/10.7208/chicago/9780226092980.001.0001

12. De Jonghe, O. (2010). Back to the basics in banking? A micro-analysis of banking system stability. Journal of Financial Intermediation, 19(3), 387-417. https://doi. org/10.1016/j.jfi.2009.04.001

13. Demsetz, R. S., \& Strahan, P. E. (1997). Diversification, Size, and Risk at Bank Holding Companies. Journal of Money, Credit and Banking, 29(3), 300. https://doi. org/10.2307/2953695

14. Elsas, R., Hackethal, A., \& Holzhäuser, M. (2010). The anatomy 
of bank diversification. Journal of Banking and Finance, 34(6), 1274 1287. https://doi.org/10.1016/j. jbankfin.2009.11.024

15. Ferrara, G., Langfield, S., Liu, Z., \& Ota, T. (2019). Systemic illiquidity in the interbank network. Quantitative Finance, 19(11), 1779-1795. https://doi.org/10.1080 /14697688.2019.1612083

16. Financial Services Authority. (2019). Indonesia Banking Statistics. Retrieved from https://www. ojk.go.id/en/kanal/perbankan/ data-dan-statistik/statistik-perbankan-indonesia/Default.aspx

17. Financial Services Authority. (2020). Perkembangan Industri Jasa Keuangan dan Arah Kebijakan Strategis.

18. Gai, P., Haldane, A., \& Kapadia, S. (2011). Complexity, concentration and contagion. Journal of Monetary Economics 58(5), 453-470. https://doi.org/10.1016/j. jmoneco.2011.05.005

19. Kamani, E. F. (2019). The effect of non-traditional banking activities on systemic risk: Does bank size matter? Finance Research Letters, 30, 297-305. https://doi. org/10.1016/j.frl.2018.10.013

20. Kim, H., Batten, J. A., \& Ryu, D. (2020). Financial crisis, bank diversification, and financial stability: OECD countries. International Review of Economics and
Finance, 65, 94-104. https://doi. org/10.1016/j.iref.2019.08.009

21. Kleinow, J., Horsch, A., \& GarciaMolina, M. (2017). Factors driving systemic risk of banks in Latin America. Journal of Economics and Finance, 41, 211-234. https://doi. org/10.1007/s12197-015-9341-7

22. López-Espinosa, G., Moreno, A., Rubia, A., \& Valderrama, L. (2012). Short-term wholesale funding and systemic risk: A global CoVaR approach. Journal of Banking and Finance, 36(12), 3150-3162. https://doi.org/10.1016/j.jbankfin.2012.04.020

23. Manurung, N., \& Moestafa, B. (2011). Bank Century Fallout Spreads as Indonesia's Mulya Investigated. Bloomberg. Retrieved from https://www.bloomberg. com/news/articles/2011-10-03/ bank-indonesia-deputy-governorinvestigated-over-loan-relievedof-duties

24. Moore, K., \& Zhou, C. (2014). The Determinants of Systemic Importance (Discussion Paper No. 19). Retrieved from https://www. systemicrisk.ac.uk/sites/default/ files/downloads/publications/dp19_0.pdf

25. Sato, A. H., Tasca, P., \& Isogai, T. (2019). Dynamic Interaction Between Asset Prices and Bank Behavior: A Systemic Risk Perspective. Computational Econom- ics, 54, 1505-1537. https://doi. org/10.1007/s10614-018-9792-y

26. Slijkerman, J. F., Schoenmaker, D., \& de Vries, C. G. (2013). Systemic risk and diversification across European banks and insurers. Journal of Banking and Finance, 37(3), 773-785. https://doi.org/10.1016/j. jbankfin.2012.10.027

27. Staum, J. C. (2012). Counterparty Contagion in Context: Contributions to Systemic Risk. SSRN Electronic Journal. https://doi. org/10.2139/ssrn.1963459

28. Valencia, F., \& Laeven, L. (2008). Systemic Banking Crises: A New Database (IMF Working Papers No. WP/08/224). https://doi. org/10.5089/9781451870824.001

29. Wagner, W. (2010). Diversification at financial institutions and systemic crises. Journal of Financial Intermediation, 19(3), 373-386. https://doi.org/10.1016/j. jfi.2009.07.002

30. Yang, H. F., Liu, C. L., \& Chou, R. Y. (2019). Bank diversification and systemic risk. Quarterly Review of Economics and Finance, 77, 311-326. https://doi.org/10.1016/j. qref.2019.11.003

31. Zeb, S., \& Rashid, A. (2019). Systemic risk in financial institutions of BRICS: measurement and identification of firm-specific determinants. Risk Management, 21, 243-264. https://doi.org/10.1057/ s41283-018-00048-2 